\title{
Through Tibet to China
}

\section{Author(s): M. S. Wellby}

Source: The Geographical Journal, Vol. 12, No. 3 (Sep., 1898), pp. 262-278

Published by: geographicalj

Stable URL: http://www.jstor.org/stable/1774313

Accessed: 27-06-2016 02:44 UTC

\section{Your use of the JSTOR archive indicates your acceptance of the Terms \& Conditions of Use, available at}

http://about.jstor.org/terms

JSTOR is a not-for-profit service that helps scholars, researchers, and students discover, use, and build upon a wide range of content in a trusted digital archive. We use information technology and tools to increase productivity and facilitate new forms of scholarship. For more information about JSTOR, please contact support@jstor.org.

The Royal Geographical Society (with the Institute of British Geographers), Wiley are collaborating with JSTOR to digitize, preserve and extend access to The Geographical Journal 
people is derived from the black races. Traces of this can easily be found down this coast and partly across the whole continent, and through the Sudan and part of Egypt. I do feel that the human element is often a little too much forgotten. I am sure we are all very grateful to Mr. Weatherley for the most interesting paper he has given us to-night.

The President : I shall have great pleasure in bringing to the notice of the Council Mr. Sharpe's interesting suggestion and Sir Henry Howorth's very supplementary remarks. I think we must have been all struck by the pre-eminent fitness of Mr. Weatherley for the work he undertook. First of all, I think we admire his kindness to the natives, his warm sympathy with them, and his keen anxiety for their welfare. We have also keen equally struck by his perseverance. This perseverance is especially exemplified by the trouble he took with his observations, when he found himself without any quicksilver, and had to use a looking-glass levelled with shot. That was an operation that would require more patience than any otber that, I think, we can imagine. It may appear to be a very small thing, but it is one among many proofs of his perseverance. He was absolutely fearless, warm-hearted and kind to the natives, and he possesses most remarkable determination. We and all the Fellows of this Society are very pleased to reflect that the Council selected Mr. Weatherley for the grant of one of our awards this year, for his eminent services in the exploration of Lake Bangweolo. For when we ask Mr. Sweet to convey to Mr. Weatherley the cordial thanks of this meeting for the interesting paper he has forwarded to us, and for his most valuable collection of photographs, I hope it may be some comfort to him in his loneliness to know that he is not forgotten by the Fellows of this Society, and that we take the first opportunity of recognizing his valuable geographical researches.

\section{THROUGH TIBET TO CHINA.*}

By Captain M. S. WELLBY, 18th Hussars.

BEFORE telling of our journey, that is, of the journey that Mr. Malcolm, of the 93rd Highlanders, and I made together, in 1896, it will perhaps be well to compare our routes with those of other travellers. Colonel Prjevalsky had attempted to reach Lhasa, starting from the Tsaidam. Bower started from the west, at the pass Lanak La, and at once struck a direction south-east to Tengri Nor. Two years before this, in 1889, Prince Henry of Orleans and Bonvalot made a journey from Lob Nor to Tengri Nor. In 1894, the Littledales made their famous journey, starting from Cherchen, arrived within 50 miles of Lhasa. Rockhill's wanderings had been restricted to Eastern Tibet. Thus it will be seen that none had attempted Northern Tibet; it had only been crossed in the eastern portions, and there lay several hundred miles absolutely unexplored.

Our main object was to traverse this unknown land, and to try and discover what lay beneath that mysterious word, "unexplored." We also announced that we were bent on finding the source of the Chu

* Read at the Royal Geographical Society, June 9, 1898. Map, p. 336. 
Ma river, a tributary of the Yangtse. Throughout the journey across this land we generally followed valleys, nullahs, and dry beds of rivers. After marching some 120 miles from Lanak La, we saw immense snowranges, running east and west, both north and south of us. The north range was particularly conspicuous, with an abrupt massive peak. Our maps will describe the country best, but it may be as well to mention the fine snow-peaks that lay some 20 or 30 miles north of us when on the banks of the river Chu Ma. For four months we saw no vegetation higher than an onion, and for nearly four months we were at an average height of 16,000 feet. For more than fourteen weeks we were without seeing any sign of mankind, and should have been a deal longer, had we not providentially met a Tibetan caravan travelling at right angles to our route, on their way from Lhasa to China. The distance we covered from Leh to the Chinese frontier town of Tankar was very nearly 2000 miles; it took us nearly five and a half months.

We made our start from Leh, the capital of Ladakh, where we spent a week or so collecting our caravan, receiving every assistance from Bishan Das, the Wazir of Leh, and from Captain Chenevix-Trench, the Resident at Srinagar. At this time of the year, namely, the end of March, men and animals are scarce in Leh, for the season is not sufficiently far advanced to allow of merchants journeying in from the north. Leh itself was comparatively empty. By a stroke of good fortune, a certain merchant had lately arrived from Lhasa, and from him we purchased the nucleus of our transport.

Our caravan, when completed, consisted of twenty-two mules and seventeen ponies. Some of these latter were in very poor condition, while the former had no cause to boast of their appearance. They carried 28 maunds of bhoussa (or over $200 \mathrm{lbs}$.), or chopped straw, and 18 maunds (over $1200 \mathrm{lbs}$.) of grain, and four and a half months' rations for all our men. In Leh three distinct kinds of mules are obtainable, namely, Yarkandis, Ladakhis, and Lhasa or Chang Tanis ; of these, the former are by far the most taking in appearance, and are mostly very big, standing 14.2 to 15 hands. They are, however, unfitted for a long journey, when grass is likely to be scarce, and only a limited quantity of grain can be carried. The majority of these mules are black in colour. The Ladakhi mules are mostly brown; they are generally extremely hardy, able to stand great cold, and to do a lot of work on inferior food. Unfortunately they are hard to obtain, as only a very small number are bred, and some are too small to be of much good. The best of all are the Chang Tanis, bought in Leh; the very fact of their being there shows that they have been able to perform a long march with Joads on their backs. They require little or no grain, and are very hardy. Yarkandi merchants, as a rule, give their mules loads of $200 \mathrm{lbs}$. to $240 \mathrm{lbs}$, and about $4 \mathrm{lbs}$. of grain daily; the Lhasa merchants put about $160 \mathrm{lbs}$. on their backs, and when grass is plentiful, give no grain. 
Our fullowers were composed of six Argoons and two Yarkandis as drivers; an Argoon cook called Lassoo; and a Ladakhi servant called Esa Tsareng, which we simplified into "Esau;" and lastly our subsurveyor, Duffadar Shahzad Mir XI. B.L., who throughout worked with the plane-table most perseveringly, while we took the latitudes and heights. There was also with us my little fox-terrier Ruby. Even in Leh we could place but little faith in our men; but as no others were forthcoming, we were entirely in their power, and could only induce them to start at all by humouring them in every way and complying: to all they asked for.

Without doubt we were starting too early in the year, for most of the passes were closed by snow; yet it must be remembered that a late start may result in winter setting in before the plateau is crossed. For this reason we could not take the direct route across the pass Chang La to Lanak La, where we wished to cross the frontier. In fact, the only way open to us lay in working our way round to Shushal, on the Pangong lake. This road we took. I shall never forget the day of departure from Leh. As soon as the signal was given for the gates of the serai to be opened, the loaded mules and ponies, who had done nothing but eating for the last few days, with one accord rushed down the main street of Leh. Some took advantage of open doors and went inside, others discarded their loads altogether, while men, women, children, and dogs all joined in the general uproar. A short way from the town the road makes a sudden dip, and here the crowd of friends and relatives of our men, not relishing the return journey, bid their last farewell amidst much weeping, whilst the more generous-hearted of the muleteers scattered small change amongst the young fry.

At Shushal, where we completed our stores of bhoussa and grain, our difficulties began. No one could, or rather would, tell us of a road running eastward. The direct route over the Marsemik La into Chang Chemmo was closed by snow; but, looking at the map, it appeared that still two other routes remained-one by the northern and one by the southern extremity of the lake. We knew quite well that the southern course would be impossible, for the strong guard maintained at Rudok were certain to turn us back for good and for all. It did, however, look feasible to find a crossing between the two lakes. We sent Esau with another man, mounted on ponies, to find this out; but they were soon stopped by a strong armed party from Rudok, who were well acquainted with our every movement, and fully determined to oppose any attempt in that quarter. We therefore adopted the only course left, and marched northwards along the shores of the lake to Lukung. From here we found the only route open was one to a place called Niagzu. A journey with two passes and of three days without water. It was a cruel beginning to contemplate for our mules, but with the help of hired yak we accomplished it without mishap. Niagzu is looked upon by 
Tibetans as a boundary-mark between Ladakh and Tibet. It is a snug spot, with a fresh rivulet and thick brushwood abounding in hares, while antelope and kiang (wild donkey) resided in some of the adjacent valleys. This brushwood was the last we should set eyes on for four months. Thence we journeyed on eastwards for some days to Lake Treb, with a guide to show us the way. This lake is of a beautiful blue, and saltish. Ladakhis come as far as this to collect the salt, of which there is abundance, and Tibetans take their ponies to drink the water for its medicinal qualities. The lake shows signs of having considerably dried up as years go by, for the banks sloped down in terraces to the water's edge. This I believe to be the case with many lakes in Tibet.

Lake Treb lies at the foot of a pass called the Napu La, which we made out to be 19,300 feet high, water boiling at a temperature of $179^{\circ}$, with temperature at $40.6 \mathrm{Fahr}$. at the summit. The crossing of it is a stiff climb for loaded animals, and would be altogether impassable after heavy snow. On descending the other side we found a fine glacier, and camped at the foot of it. At this point our hired transport left us to return to Lukung, and afterwards we only had ourselves to depend upon. We found a broad well-watered valley running east, while on either hand were occasional grassy nullahs, wherein dwelt goa and antelope, and numbers of ovis ammon heads lay about. As we marched down this valley we overtook two or three Tibetans, and, having won their friendship by means of small presents, persuaded them to act as guides. They informed us that if we continued down the valley, we should enter a district called Rundore, and there meet with opposition. They were astonished to find we had come so far without encountering anybody, and only accounted for it by saying that many Rundore men had been summoned to Rudok to strengtben that post, for news had reached them of a strong expedition setting out from Leh in that direction. Nevertheless, they agreed to take us up another valley running northwards, called Kerambutabuk, and thence east as far as the Mangtzatso, and so avoid all collision with the Rundore men. This strategic movement was doomed to failure, for at our first night's encampment we were visited by some Rundore officials with an armed following.

These men were at first bent on opposing us, but finally gave way to persuasion, and just as we were congratulating ourselves upon our good fortune, another strong party of officials from Rudok rode in, in hot haste, determined to stop us. Bribes, threats, and arguments were of no avail. They insisted upon our returning by the way we had come. Throughout the night fresh arrivals continued to pour in, and the jingling of the bells on the ponies' necks proclaimed at what a rapid rate they rode. At daybreak we found quite a big gathering, armed with spears and matchlocks. In an ostentatious way we loaded our mules and our guns, and, distributing them to our followers, endeavoured to get past. But the Tibetans, whose actions and feelings were those of 
fanatics, were not to be so taken in. Back we had to go, and, without hired transport, to recross the Napu La, back to our old friend, Lake Treb. At the corner of the Kerambutabuk nullah where it joins the main Rundore nullah, was a small nomad encampment called Kerinagar. These people lived in some very dirty and dilapidated old tents, and possessed a little grain and a few sheep. Close by was a hill called Chotenchenbo, conspicuous amongst a chain of others. The hill is probably volcanic, as these nomads informed us that every month much noise was emitted from the summit, which has so worked upon their imaginations that they hold it in the deepest veneration, and on the 15 th day of each month, numbers of people from the surrounding district come to worship and propitiate the spirit of the mountain.

From Lake Treb we travelled north to the east side of the pass Lanak La. Since leaving Leh we had traversed 397 miles, had lost two ponies from exhaustion, and all our sheep but one, yet we had only just reached the border of Tibet. This solitary sheep marched for several weeks to come, and very often, when game was scarce, his life was in jeopardy; he was friends with everybody. One day, however, he had to be killed to supply mutton broth for one of the men who was seriously ill. But, owing to his daily tramp, the flesh, we agreed, was the hardest and toughest we had ever tried to eat, and I am sorry to say the mutton broth possessed so little sustenance that the poor man died. But here we received an addition to our party, in the shape of Ruby's litter of three pups. Our men, too, at this spot, were exhibiting a grumbling spirit, and were hinting at turning back; fortunately, Malcolm shot a yak, and their minds, for the time being, were fully occupied in cooking and eating an enormous amount of flesh.

On May 31 we at last launched forth over northern and unexplored Tibet, which is known as the Chang. We had hoped to find either Bower's route or the Polu road before taking our own course, but.our reconnoitring availed us nothing, so we resolved to strike a road for ourselves. We decided, whenever possible, to march due east, and when in doubt to travel north rather than south. We started over an easy pass, and on the other side found a broad valley running east, and camped in it the same evening, by two small pools of fresh water, though there was next to no grazing. Throughout the night a violent storm raged. We could hear our mules entangled in the guy-ropes of our tent in their eagerness for shelter, and every moment we expected to be buried in snow and canvas. On rising at daybreak, a death-like silence prevailed, so still it seemed after the previous night. Stepping outside, I found all was clothed in snow. The men were quiet in their tents, and some of the mules stood with drooping heads, and others lay outstretched; but, on counting them over, several were deficient, and the poor fellow who had nearly brought the tent down on our heads lay stiff and dead. I woke up the camp, and, selecting our best men 
and ponies, sent them off to track the strayers before the snow melted.

I will now pass more quickly over the next two months. Throughout the month of June we continued to travel eastwards. Our animals died at an alarming rate, so that Malcolm and I had to give up all idea of riding. Generally speaking, our route lay along broad open valleys some 16000 feet high, and after every four or five days, we would cross an easy pass into another wide valley. It was clear that the range of mountains ran east and west, and it struck me that the difficulties of travelling north and south must be great. The land abounded in salt lakes and salt districts, making fresh water very scarce; in fact, almost daily we had to dig some feet deep, before we could hope to find any. This want, added to the scantiness of the vegetation, told severely on our animals. By June 22 twenty-three of them had died, and some of the remaining sixteen were in a very weak condition; yet, since leaving Lanak La we had not come 200 miles. In some places we found grass just beginning to sprout, showing the advantage to be gained of making a later start in the season, if possible. In others we found "boortsa" growing, a kind of heather. In this there is certainly a great deal of nourishment and saline moisture. Most of the animals generally preferred it to grass, and required less water when it was plentiful. Our ponies gave way before the mules.

On June 9 we camped on the banks of a fresh-water lake, frozen over. As we had to lighten our loads here by leaving goods behind, we christened the lake, Lake Lighten. On June 18 (camp 32, height over 16,000 feet), we found a small white butterfly. At these high altitudes, it was astonishing to find the thermometer registering as much as $110^{\circ}$ Fahr. in the sun, while at night-time there were sometimes $25^{\circ}$ of frost. Very soon after sunrise the heat became most oppressive for the mules and ponies, and, in order to husband their strength, we used to rise at 3.30 a.m., and march half a dozen miles, and again make a second march in the cool of the afternoon. During this month game was scarce, but towards July things began to improve. Game became more plentiful, especially yak, some of which, on one occasion, were even grazing with our own mules. Salt lakes became rarer, there was better grazing, and we were able to add to our collection of flowers. On July 12 (camp 52), we saw eagles and wild dogs. On July 19 (camp 59), a week later, we found a brown butterfly.

On July 22, just after leaving camp 63 , we crossed a narrow track running at right angles to our route; this was well defined, and perhaps a road to Lhasa. On the track, one of our men picked up the entire legbone of a pack-animal, showing clearly that a merchant or traveller must at some time or other have used the track, for there was a shoe attached to it, and nomads do not shoe their animals. This track ran along the western edge of an ancient dry bed of a salt lake. The lake was 
remarkable, for it was divided into small squares by walls of crystallized salt, 2 to 3 feet high. The salt was of excellent quality.

On July 27 (camp 68), we crossed a river, which took its rise from the hills close by. The bed of it was half a mile across, with several small streams a foot deep, and it was the largest body of running water we had met. Everywhere grew good grass, flowers, wild onions, and other vegetables_-"kumbuk" and "hann." Yak and antelope were abundant.

'Throughout this time we had experienced a good deal of trouble from our muleteers. We could not make them realize that our only chance of crossing this unknown land lay in taking every care of the mules. Our arguments and promises of rewards bore fruit for a few hours only; the slightest reverse would again exhibit a lazy and unwilling spirit. Besides, they quarrelled amongst themselves, chiefly, I think, over their rations. We could never trust them out of our sight. One of us would march with them, while the other reconnoitred some miles on ahead. Shahzad Mir, with his pony, was left alone to continue his surveying without interruption. On August 2 a climax was reached, when I upbraided the muleteers for their laziness. We could not induce them to rise and load their mules, and I told them that if they chose they might remain where they were, but that Malcolm and I intended to march. There and then they rose in a body, and seizing whatever they fancied, including the remaining 20 lbs. of flour and the meat, and headed by the caravan-bashi, Ghulan Rassul, marched off in a south direction. This man, who had been with Mr. Littledale on his last journey, had deluded them with the idea that he could guide them to Lhasa. Although we had been warned by the Wazir of Leh against making Ghulan Rassul our headman, still there was no other man at all fitted for the post. We now composed a small party; besides our Duffadar, there remained Lassoo and Esau, twelve animals, and Ruby. Reducing our baggage, we eventually caught the mules and loaded up, and made a long march that same day. But on the second day after this the deserters reappeared; they had had enough of finding their way to Lhasa, and were evidently not on good terms with one another. They begged us to take them on again; but this, with the exception of one man, Shukr Ali, we did not feel it our duty to do, more especially when we learnt from Shukr Ali that there had been a pre arranged plot, even as far back as Shushal, to leave us when food ran short-furthermore, that they had planned to steal our animals at night-time, and leave us without means of transport and without food. This we had guessed, and had hidden and watched by night, and continued to do so till we knew we had shaken them off. Had we felt we could have relied upon their faithfully serving us, we would have taken them willingly, and were anxious to do so; but we could not trust them, and even now I am convinced that had we done so we should have paid heavily for it. 
After this misfortune, we were lucky in finding good grass, fresh water, onions, rhubarb, and game. On August $9 \mathrm{I}$ shot a somewhat remarkable animal at a height of over 16,000 feet. The skin I have here. Two young cubs we carried along with us in hopes of their eventually reaching India. All went well till August 10, when, through the exhausted state of our mules, we were forced to camp at the summit of a pass, 16,614 feet high. There was no grass, but certain hardy plants. On the following morning we were astounded to find nine of the mules were dead. Everything we could possibly do without had now to be abandoned; in fact, we only kept one tiny tent, our bedding, ammunition, and instruments, and the clothes we wore, and we left our two cubs behind with a large supply of meat. We commenced the descent of the pass a sadly reduced party, each with loads on our backs. The weather, which hitherto had been all that could be desired, became very broken, and the going was consequently very heavy; whereas latterly we had been making some 16 miles a day, we now had difficulty in covering half that distance. To add to our troubles, game was very scarce.

Since the day of this misfortune we had been gradually descending, following a small stream which daily increased in volume, and we hoped that this would eventually bring us to people. Our food was kiang and wild onions when we could find any. For ten days we stuck to the stream, crossing and recrossing, when sometimes the three mules would collapse midstream, which flowed fast and cold and about 3 feet deep. At length, on August 22, we found ourselves on the shores of a magnificent fresh-water lake. Everywhere grew rich green grass. On the north side of the lake, along which our path lay, rose grassy hills teeming with wild yak and kiang; above and beyond these were snowcapped ranges. On the south side a vast plain stretched far away to distant mountains. Around the edges of the lake lay perfect skeletons of scores of dead yak. All seemed to choose the shores of this wonderful lake to die by. Flowers, water-fowl, and hares were plentiful. The shore was sandy, with rocks around, reminding one vividly of an inlet sea. It was indeed an artist's and a sportsman's paradise. The lake was about 23 miles long and 4 miles broad in places. At 7 p.m., although nearly 16,000 feet above the sea-level, the temperature registered nearly $50^{\circ} \mathrm{Fahr}$; during the night it only just froze. At the east end of this lake were some sandy hillocks, and a trickling stream took its rise from the adjacent hills. As this stream ran in an easterly direction, we resolved to follow it up in hopes it would bring us to people. Each day the stream increased in volume, so that we dared not cross it. At that time we had even run out of salt, and when we shot a yak, we used to boil down its fat into cakes, and munch it like Everton toffee.

On the 12th day, after we had followed the stream for 120 miles, we providentially fell in with a large caravan of Tibetan merchants. They 
were travelling at right angles to our route, and were on their way from Lhasa to Tankar, situated on the borders of China. Since leaving Lanak La we had been marching for fourteen weeks, and had traversed very nearly 1000 miles, without seeing a sign of mankind. This caravan had been two and a half months on the road, and expected to reach Barong, in the Tsaidam, in about another month. From them we learnt that the river we had followed was no other than the Chuwa, whose very source we had found. They told us that it flowed through the Golok country, thence on to Tachien-lu, into the Yangtse. This probably flows to Batang, as there is no big river at Tachien-lu. Merchants going by the eastern route would pass through Batang and then Tachien-lu.

A few words about this Tibetan caravan may be of interest. The head of the caravan was a verv fine-looking mibetan from Lhasa, standing over 6 feet high, and alway's known as the "Kushok." The title "Kushok" was originally applied to living Buddhas, but latterly it has become merely a term of respect or affection, and no longer has any religious significance. Next to him was another important merchant, who shared his tent; then there were several minor ones, who owned perhaps only a few yak; besides these was a lama, or priest, and herdsmen, cooks, and servants, all mounted. There were some 1500 yak and 300 ponies, and altogether they made up an imposing caravan. The fifteen hundred yak were divided into seven distinct companies, moving off in column; and these seven were again divided into two wings. They always marched off in the same order, without the slightest noise or confusion. The yak were always loaded in the dark, and they moved off before sunrise, and although we used to pitch our tent next to the Kushoks, they used to march off without even waking us. By marching after them, we were able to carry out our observations and sketching without arousing suspicion. One day, the Kushok, seeing Shahzad Mir coming in last, carrying the plane-table, asked, "What offence has this man done, that he merits this daily punishment?" $\mathrm{He}$ fancied we had adopted some variation of the Chinese infliction of wearing the wooden collar, known as the "canque." No food was eaten in the camp till after the march and after unloading. If there was one thing more than another which aroused our wonder in connection with the caravan, it was the extraordinary knowledge the Kushok had of every little thing that went on. Outwardly he appeared to take scarcely any interest in anything. He rarely came outside his tent, and seemed to spend most of his time in drinking tea and praying.

The Lhasa-Sining route, along which we were now travelling, is no regularly defined road, but every year the caravans renew various old landmarks, and set up new ones on prominent places, generally to denote the camping-grounds. It may sometimes occur that no caravan has done the journey for two or three years, and if the landmarks are not carefully kept up, there might be great difficulty in finding grass and water. For this 
reason their marches vary in length, from a few miles to 30 a day. One caravan only leaves from each end every year. The annual tribute from Lhasa to the Chinese Emperor does not travel by this road, but by Labrang. They usually start in May, taking about five months on the journey. A caravan from Lhasa to China brings the famous pulo cloth, and great quantities of dried dates (kasur). These come into Lhasa from Calcutta, so that by the time they reach China they are naturally very expensive, almost a penny each in English money.

Caravans from China to Lhasa are mostly employed carrying tea, the main staple of food in Tibet, and some tobacco. The reason why only one caravan goes each year is, that all the merchants are very much afraid of encountering robbers on the road. Very often these large caravans are employed trading for the Talè Lama or other high officials in Lhasa, but whether this is invariably the case, or whether on this occasion, I am unable to say. In matters of business, as well as of geography, the Kushok and his servants were very reticent after the first day or two. At first he used to invite us to tea in his tent, but afterwards we had to pay a rupee for this luxury. The Kushok did impress upon us that the determination to prevent foreigners entering Lhasa was greater than ever. At Tankar, the frontier town of the province of Kansu, there are four Tibetan officials appointed by the Talè Lama to look after the interests of Tibetan merchants, and to arrange any difficulties arising between them and the Chinese.

On September 14 we reached brushwood, the first since Niagzu, and camped on the right bank of the river Shugatza, or Shuga Gol, which at this point flowed through hills in a north-west direction. The river here was some 30 yards across, and from 3 to 6 feet deep, with stony bottom. On both banks was good grazing. South of us lay the Tong hills. Two days later we left the merchants under peculiar circumstances, and next morning found a hot spring bubbling up from the top of a rock standing 4 feet high in the middle of a nullah close to the Shugatza. The water was fairly hot, but tasteless, though the rock was stained a black and yellow colour. It was apparent, from the surroundings, that people frequented the spot. The following day we left the river, which flowed from a more southerly direction, while we steered for some white rocky hills at the entrance of a nullah. All the way up the nullah were skeletons of dead yak, showing what hardships some previous caravan had undergone. We also picked up a keg of opium.

After crossing the first range of hills, we came to a small hill at the entrance to another nullah; on the summit was a large pile of stones decorated with sticks and red rags. This was evidently a campingground. The spot is called Dapsoga, and the little hill Ser. Close to here the Namoran Gol takes its rise, and it is the junction of the two roads into the Tsaidam, one leading over the Namoran Dawan, and the 
other more west, the Burhan Bota. The latter, though a little longer, is the one generally chosen, for it is more suited to laden yak, which are liable to get lost and scattered in the thick bush over the former.

On September 21, camp 122, on the banks of the Namoran Gol, we found brushwood 8 feet high, and afterwards wild currants and other berries, which Ruby ate voraciously. We also came to a stone building, 12 feet square, wherein was a huge prayer-wheel, for ever being turned by the force of water. Hanging about on the bushes were numbers of prayers on linen, the largest one of which I seized and have here. Close by Malcolm shot a bear (Ursus pruinosus). After crossing. these ranges, we entered a desert plain, till eventually, in a desperately hungry condition, we fell in with Mongols, the Tsokpo or Sokpor Mongols, who were living with their flocks in the bush. At this place the Namoran Gol splits up into several small streams, and there is good grazing and thick bush. We journeyed two days east with these Mongols, to their tents on the banks of the Bayan Gol. On the way we crossed a salt district, and the river Shishi. We were now in the district of Dsun, some 10 miles north of Barong. Just south of Barong is another pass called Hato, which runs into the Lhasa road; but it is hardly used, and not a recognized road, like the two others mentioned. The climate on the Bayan Gol is, I am told, most genial all the year round, for it seldom rains or snows, though they can see it raining in the mountains around. These Mongols were most unsophisticated, and persisted in taking pinches of Cadbury's cocoa, which they maintained was snuff.

We lived with these people for three days on the river, meeting with great kindness and hospitality. We were endeavouring to persuade them to help us with ponies into Tankar, a distance of 300 miles. They told us we could get camels at Barong, but with so small a party the owners would not dare to go. They would have to pass through a district inhabited by the Bana tribes, shown in the map Banakhasum - sum meaning "three;" that is to say, there are three of these Bana tribes, and these again are subdivided into eighteen small tribes, each with a separate chief, the whole being under the Sining Amban, or Tsong T'u. It is through fear of these tribes that the Tsokpo Mongols so seldom make the journey to China. At length we persuaded some of them to help us, and on October 1, we left the banks of the Bayan Gol, accompanied by Lobsan, an influential Mongol, and whose real name is Dsun Choni Lama, and three other men and ten ponies. As we drew near the black tents of the Bana tribes, Lobsan and his men thought it as well to rehearse a battle by night, so that all might be prepared. Soon after sunset, big fires were made to represent a big camp, when they pretended that imaginary enemies had fallen upon us. They fired off their matchlocks, and rushed here and there, crying out, "Ho! hi! ha!" Malcolm 
and I sat by a large fire of argols, warming our toes as we watched the terrible battle they were engaged in.

On the third day we hit off the main track running from Barong to Tankar, and, after crossing an easy pass, where was a stream whose water was considered poisonous, for it was never drunk by man or beast, we dropped down into the valley of Noring Gol. Here lay a salt lake, where we saw the first signs of the late Mohammedan rebellion, for there were two deserted and ruined Mongol villages, devastated by the rebels in their flight from China into Turkistan. The crests of the hills in this neighbourhood were clad with pine trees. On the sixth day of our march we hit off the Tuling Gol river, and the next day saw signs of a large encampment, where the Chinese had halted in their pursuit of the rebels. A short distance further on was the village of Selling Gompa, where I was told the French traveller, Dutreuil de Rhins, had met his untimely end.

At this spot are two roads to China: the right-hand one runs through a salt district, and, though shorter, is a rougher road, and more dangerous on account of the tribes. We chose the left-hand one, and after 10 miles came to a wonderful rock called Kanjur Rungyum, which means " Sacred writings, not built by men." On one side of the rock was a courtyard, built of big blocks of white stone, some of which were 2 feet long. On many of the stones were Chinese and a few Tibetan inscriptions. Hanging across one wall was a string with hairs from horses' tails, and bones with inscriptions on them attached to it. On entering the courtyard, we found a cave, some 30 feet high, inside the rock, and there is the entrance here of a subterranean passage, which is said to run all the way to the salt lake of Koko Nor.

Soon afterwards we crossed an easy pass, the Nicotine Kotal, to a spot called Utu by Tsokpo men, and Bara nullah by Lhasa men. There was good grass, but the mountains, except where pine-clad, were barren and rocky. Later on we crossed the river Buka, ${ }^{*}$ which ran into the Koko-nor. We found the bed of the river a quarter of a mile across, the water being split up into channels some 15 yards broad. The water was 2 to 3 feet deep, and flowed over a stony bottom. This river we followed till we reached the cairn of Hatuturgy, on the west of Koko Nor. Here, on October 10, we experienced the coldest night of our journey, which we spent in the open without shelter. There were $27^{\circ}$ of frost.

We travelled along the north edge of Koko Nor, where we overtook immense numbers of yak, laden with wool and salt, on their way to China. There was fine grass land throughout, and great numbers of black tents of the Bana tribes. While marching along the shore, we had just been able to make out the island away towards the south side, but no two men

No. III:-September, 1898.]

* Buhain Gol (?). 
gave the same account about the inhabitants, and travellers have varied in their accounts about it. Later on, we were able to get a reliable statement about this "Dragon Colt's island," as it is called. There are twelve or thirteen priests living there, who keep sheep and goats, and, being free from depredations of wolves, the flocks thrive well. In winter, when the lake is frozen over, they cross to the mainland and lay in stores for the summer. After crossing a pass, we followed a stream, the Hsi Ho (West river), or Ta Ho (Big river), or Chuchok by Mongols, which brought us to the frontier town of Tankar, or Donkyr as it is shown in some maps.

The town was crowded with Chinese, and a sprinkling of Mongols and Tibetans. We received every civility from the officials of the place, more especially from the colonel commanding the troops. But as all had been disbanded, it seemed strange that he should still be in command. Tankar lies in a kind of hollow, commanded from all quarters by hills and rising ground. The chief hills are Ho-la, or Ta Sand, lying north-west; and Toai Ta, or Wupu, lying south-east. From the summit of this hill, the town of Sining, 30 miles off, can be seen; and a tree is planted on the summit, as a landmark to travellers. The chief importance in Tankar consists in its being the most westerly town of the province of Kansu, and commanding the roads to Koko Nor and Lhasa. The merchandise imported there is carried further on to Lanchau and Peking, etc. At Tankar itself very little buying and selling goes on. The wool, for instance, is forwarded by a Chinese agent to Peking by camels or by raft.

Thence, under the guidance of Mr. Rijnhart, a missionary, who was living at Tankar with his wife, we rode on to the monastery at Kumbum. He had spent two years at Lusar, and ten months in the monastery itself, and had made friends with a very large number of its inmates, more especially Mina-Fuyeh, one of the greatest incarnate saints in the place, and in whose house we were to spend the night. For the first 15 li our road lay along the left bank of the Si Ho, till we crossed it by a cantilever bridge, close to the village of Hsang Ho Pi (Sounding river), where is a small inn. We then crossed the pass Wu-la, from the summit of which we were able to note the results of the recent Mohammedan rebellion. Every village that was not in ruins had loopholed walls and fighting-towers, which had been specially erected. Rich and fertile though this little bit of Kansu is, with its crops of wheat, barley, oats, millet, peas, linseed, and opium, it will be two years before it can recover from the trying times it had passed through. The moon was high in the heavens when we reached our destination. Our continual knocking at the great wooden gates of the monastery sounded loud in the still frosty night air, but at length they were opened by one of the Greek manservants, who, on seeing Mr. Rijnhart, was all civility. While word was being sent to Mina-Fuyeh, we busied ourselves with our horses, and 
soon afterwards mounted the stone stairs, and, after crossing an open court, were ushered into the presence of one of the highest men in the eastern border of Tibet. On arrival at the monastery, we received every kindness from the saint Mina-Fuyeh, a man of twenty-seven years of age, and is now in his sixteenth or twenty-second lifetime. He is a man considerably below medium height and of slight build; he has a very pleasant face, especially when lit up by a happy smile, as it often is. His explanation of how he came to be recognized as the reincarnation of the previous Mina-Fuyeh, shows how convincing the proofs of identity are to one who has been brought up to accept and believe in the theory. He relates how, when very small, various articles had been laid before him, from which to select those he had used in his previous lifetime. Amongst these was a number of "rosaries," from which he had no difficulty in choosing his own. "For," he says, "I had used it daily for years. How is it possible that I should not know it amongst all these others?" So on with other articles; his identity was established without a doubt, and he became the heir to the accumulated property of fifteen former lifetimes. He talks freely of his last lifetime, pointing out the site of the house in which he lived, and which was burnt down about two years before his death. "It was," he says, "a far finer house than the one I now occupy." In Kumbum there are about seventy of these "incarnate saints," and Mina-Fuyeh ranks sixth or seventh. He was a liberal-minded man, and told us about the monastery, and told us to go wherever we chose, and take pictures of whatever we wanted.

Kumbum itself lies at the junction of two small valleys, one coming from the east, the other from the south, the buildings lying to the south of the former, while on the north is the "Precious Hill," which keeps off all evil influences. On the east side of the other valley are most of the private dwellings, while on the west are temples. Altogether, in Kumibum there are close on 4000 priests, about 70 per cent. of which are 'Tibetans, 20 per cent. Mongols, and the remainder Chinese. It has, I believe, been stated that Kumbum is entirely Chinese in its government and organization. That this is not the case needs no further proof than the fact that in all things temporal it is under the Tsong T'u or Prince of Koko-nor, a mandarin appointed by the emperor to govern all his Tibetan dependencies in this direction. He lives at Sining, and is known among Tibetans and Mongols as the "Seling Amban;" on the other hand, if Kumbum were really Chinese, it would be subservient to the Fu of Sining, and would be governed by the Fu T'ai. There is, moreover, a distinct boundary-line, separating the territory which comes under Fu T'ai from that which comes under the Tsong T'u ; those living witbin the boundary paying taxes to the monastery, while those outside pay to Sining Fu.

All the private houses at Kumbum are supposed to be whitewashed annually, but, like many other things, had been neglected owing to 
the rebellion. The method of whitewashing appears strange to us, for the custom is to mix the wash, then to ascend the roof and pour it down over the walls. The result is not quite satisfactory, but customs like this cannot be altered. We visited each temple and hall in succession. Perhaps the chief feature of the place is the "Gold-tiled Temple," the pride of Eastern Tibet, the sacred shrine of Tsong K'aba. At the entrance to the shrine were a few lamas kotowing, and the boards in front of the doorway have been worn away to the depth of 3 or 4 inches. Most of these lamas knew Mr. Rijnhart, and stopped in their devotions to speak a word of welcome to him; and one of the doorkeepers asked why we did not knock our heads before entering. To this Rijnhart replied that it would be no sign of respect on our part, as our custom was to remove our hats on entering a sacred place; nor did we ever omit to do so. The figure of Tsong K'aba is considerably above one, in a sitting position, and not easily seen in the dim religious light. It is about 8 feet high, I should say, and very richly gilt. Below and in front of him is the shrine, with the usual holy-water vases and butter lamps, with handsome gold and silver lamps on either side, and a fine pair of elephant-tusks. Next in interest to the golden image, among the relics in the temple, comes the stone on which Tsong K'aba's mother sat when delivered of her saintly son. We then ascended to the second floor, where we were on a level with the image. There was yet another story, from which we looked down on to the lower portions of the gilded roof. The priests say there is a quarter of an inch of gold over the roof, but, even deducting a great deal, it must be of immense value, and one could not help wondering how it had escaped the two rebellions in the last thirty years. One would have thought they would have risked anything to secure such loot, and to deal such a blow to the rival religion as the sacking of this temple would be.

On the right of the gold-tiled temple were two small temples of Sakya Muni. There is nothing in them peculiar, merely the ordinary ornaments and lamps; but just in one corner is the original "Sacred Tree," which sprung, according to some, from Tsong K'aba's hair, according to others, from his swaddling clothes. However this may be, the fact remains, that on its leaves a true believer can distinctly trace the figure of Sakya Muni, or his name in Tibetan characters. Some priests say that one thing is to be seen, and some another, but Mina Fuyeh says that on some leaves the figure may be seen, on others the characters. As only firm believers can trace anything, the question is likely to remain in doubt, in spite of Abbé Huc's assertion that he detected images. Mr. W. W. Rockhill states that he was informed by Mr. W. B. Hemsley that this tree is the white sandalwood.

From the public reading-hall we went into that for private reading -a fine room with rows of low forms about 6 inches high, comfortably cushioned, and big enough to hold 2500 priests. In front of this is 
another courtyard, in which, we were told, it is no unusual sight to see 1200 or 1500 pairs of shoes, belonging to students inside. How any one can find his own again on coming out is a mystery.

From Lusar the road lies over an easy pass into the southern valley, which it follows right up to the western gate of the town. All the way to Sining signs of the rebellion were plentiful, just as they had been on the way from Tankar. The whole countryside had been devastated by the Mohammedans while they had had the upper hand; but at the city gate the tables were turned, for hanging in cages on the wall were the heads of the ringleaders. At the mission-house we were most hospitably received by Mr. and Mrs. Ridley, of the China Inland Mission. He kindly gave me all his notes about the rebellion, to make whatever use of I wanted. They were shut up in Sining, the very heart of the rebellion, for some months, and did much good attending to the wounded.

Although this outbreak of religious enthusiasm was of no small importance, it was drowned by the Japanese war, on which the whole attention of Europe was centred. It struck me as almost incredible that the Chinese Government, although well aware that the "Salar" Mohammedans were a most restless and fanatical sect, and also that, although the previous rebellion had only ended some twenty years ago, still at the present outbreak there were no adequate means at hand to cope with the insurgents. Consequently, the rebellion grew so rapidly that before soldiers could arrive from the seat of the Japanese war, close on 40,000 Chinese in Sining and the district had been slain, and nothing but the really splendid behaviour of the chief military official, General Teng, unsupported by trained troops, prevented the town falling into the hands of the rebels. By the time Sining was relieved the trouble had grown to such an extent that the Russians in Turkistan had begun to move troops, in anticipation of the Mohammedans following the example of their co-religionists in the East.

At Sining we hired mules and started for Lanchau, where we looked out for landmarks mentioned by previous travellers. In the first day's march there were two such landmarks, or, more correctly speaking, there should have been two; the first, 30 li from Sining, a bridge over the Hsi Ho, mentioned by Mr. Littledale; the second, another $30 \mathrm{li}$ on, was the "Peh Ma Sei," or White Horse temple, mentioned by Mr. Rockhill. Unfortunately, these are now things of the past; the bridge was swept away by a flood soon after Mr. Littledale saw it, and the White Horse temple was utterly wrecked by the fanatical Mohammedans.

At Lanchau, famous for its tobacco, grown and manufactured there, kind missionaries again helped us in getting carts to take us on to Chungwei, a week's journey. This was the first town where we experienced incivility, and became well aware of the hatred of Chinese to foreigners. In these districts we found coal-mines, pewter, iron, 
saltpetre, and soda; the latter is dug out and burnt all day and night in big fires of weeds to cleanse it. We also learnt, for the first time, that Mr. Littledale's remarks before the Royal Geographical Society, about sending unprotected Swedish girls to live in out-of-the-way parts of China, had given serious offence. We were assured that unmarried girls were never sent out to stations alone, but were invariably sent to live with a married couple, and every precaution taken to guard them from any danger. At the same time, there is no doubt that Mr. Littledale's intention has been misunderstood, and could this misunderstanding be cleared up, I think it would be all for the better.

From Chungwei we took a flat-bottomed wool-boat to PaoT'eo (Bautu), and thence carts to Peking, where we underwent perhaps the strangest sensation of the whole journey, when, with the grime of our eight months' travel, we suddenly found ourselves in Lady Macdonald's drawing-room. At Peking, which had taken us so long to reach, we could only dwell for three days, for the Gulf of Pechili might be frozen over at any moment. At Tientsin, on arrival at the Globe hotel, we were looked upon with the gravest suspicion, and only with the greatest difficulty did we manage to secure one small room between us. A little later, when our landlord found out who we were, he was profuse in his. apologies, and anxious to put us in better quarters, explaining that. he at first had taken us for robbers. This was rather hard, after having had baths regularly for the last four days, having shaved our beards, and having borrowed clothes from Mr. Hugh Grosvenor at Peking, but it made us realize what a shock we must have given Lady Macdonald on our first appearance in her drawing-room.

Without the help of my friend Malcolm, I am quite sure this journey would never have been accomplished; nor can we ever forget the valuable help afforded by Shahzad Mir, nor the ready and willing spirit with which our two servants Esau and Lassoo served us throughout. The former returned to his regiment, and the two latter to their homes in Ladakh.

Sometimes, on cold nights, when reduced to a small party, Malcolm and I used to sit with our men round the fire, and tell them of the pleasures and advantages of civilization. Esau and Lassoo had never seen a boat, and pictured to themselves a life of eating, drinking, and smoking, without work. But on realizing they learnt that civilization was not without its drawbacks, for the first day at sea the cigars we had given them lay scattered about, and they lay prone and sick, and longed to be back in the middle of Tibet by the most dreary salt lake. Like other travellers, we found it our hardest task to part with Shahzad Mir and these two men.

Before the reading of the paper, the Chairman (Lord Belhaven and Stentor) said : I am sure you will be as sorry as I am that our distinguished President, Sir 


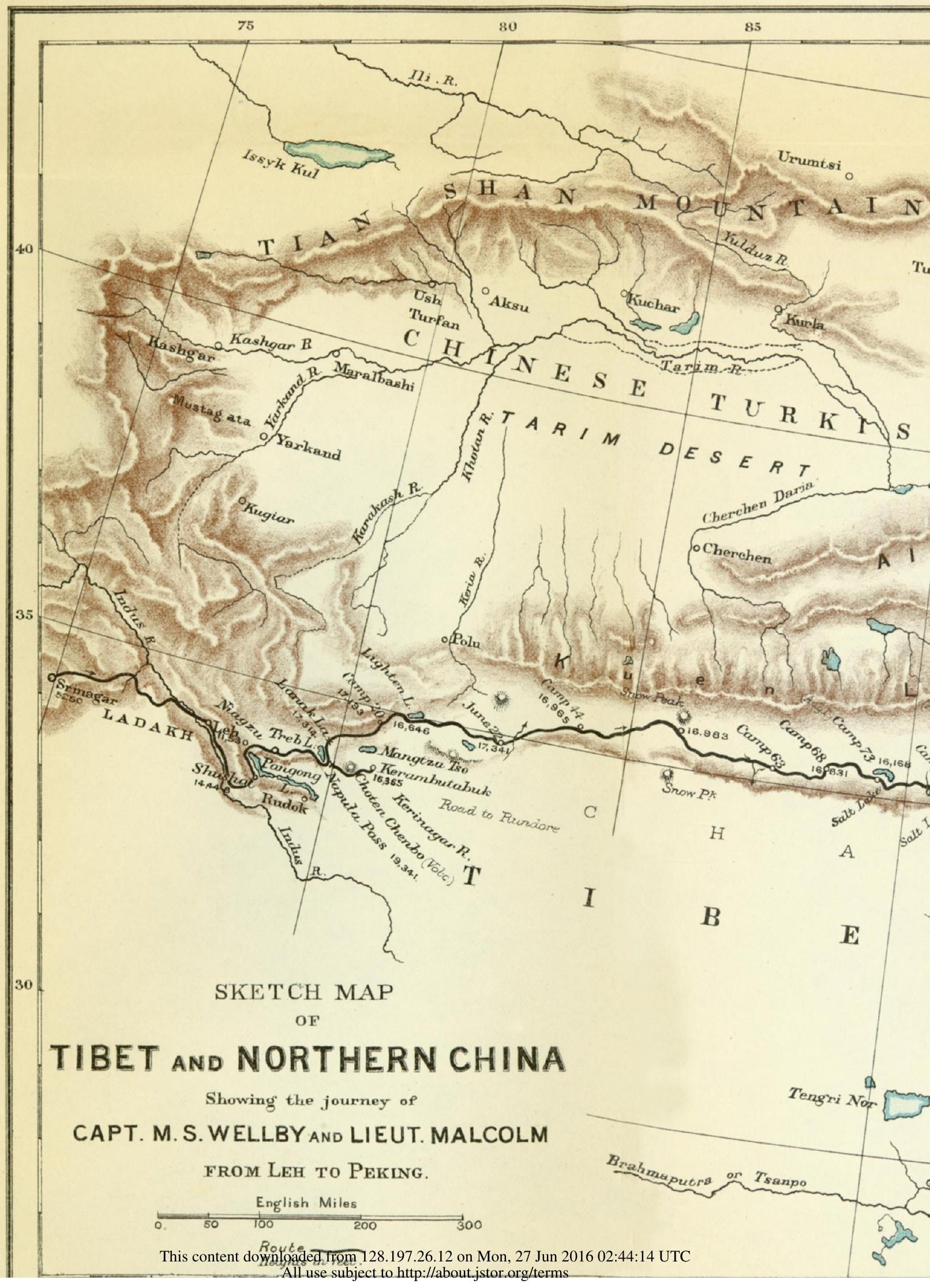




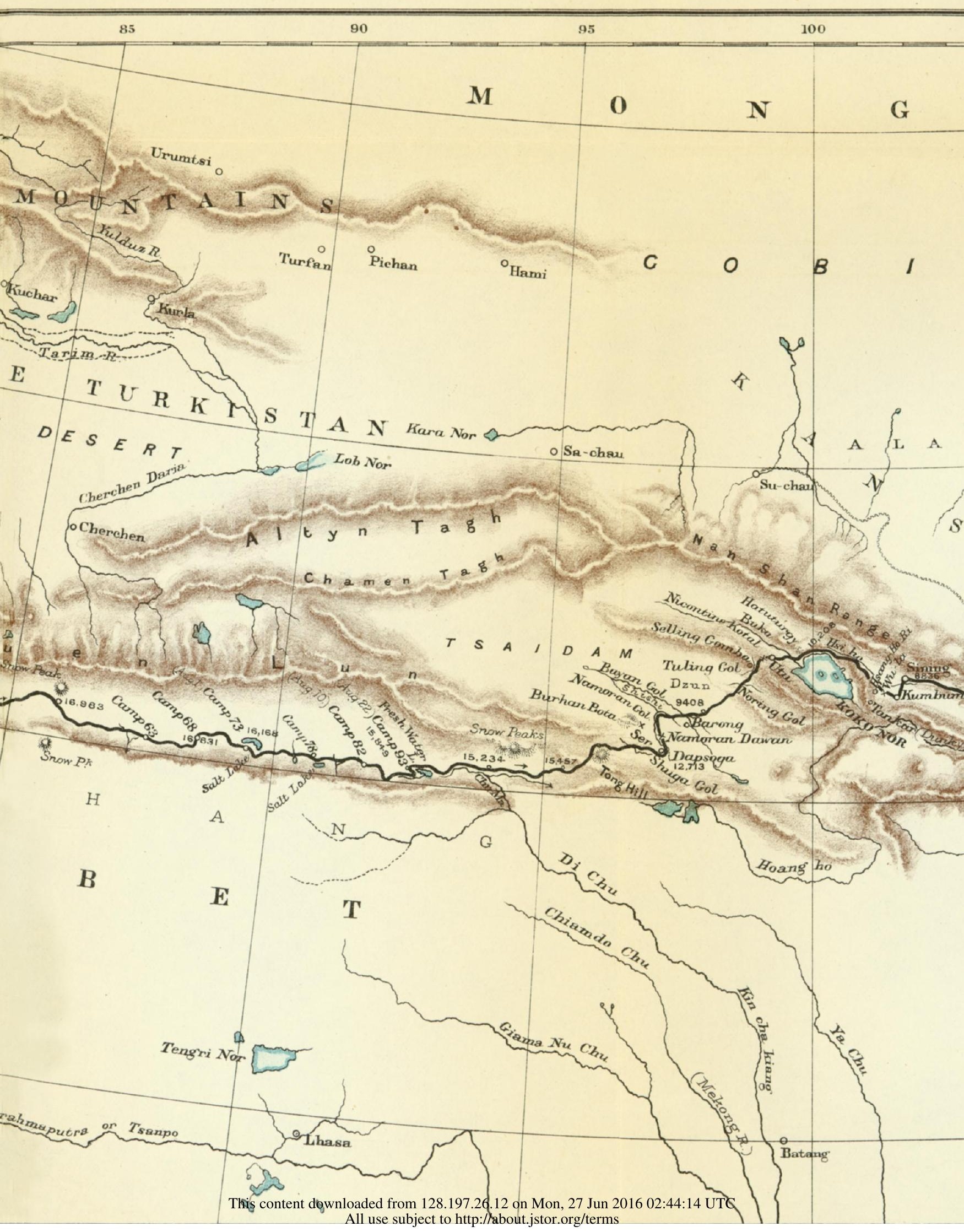




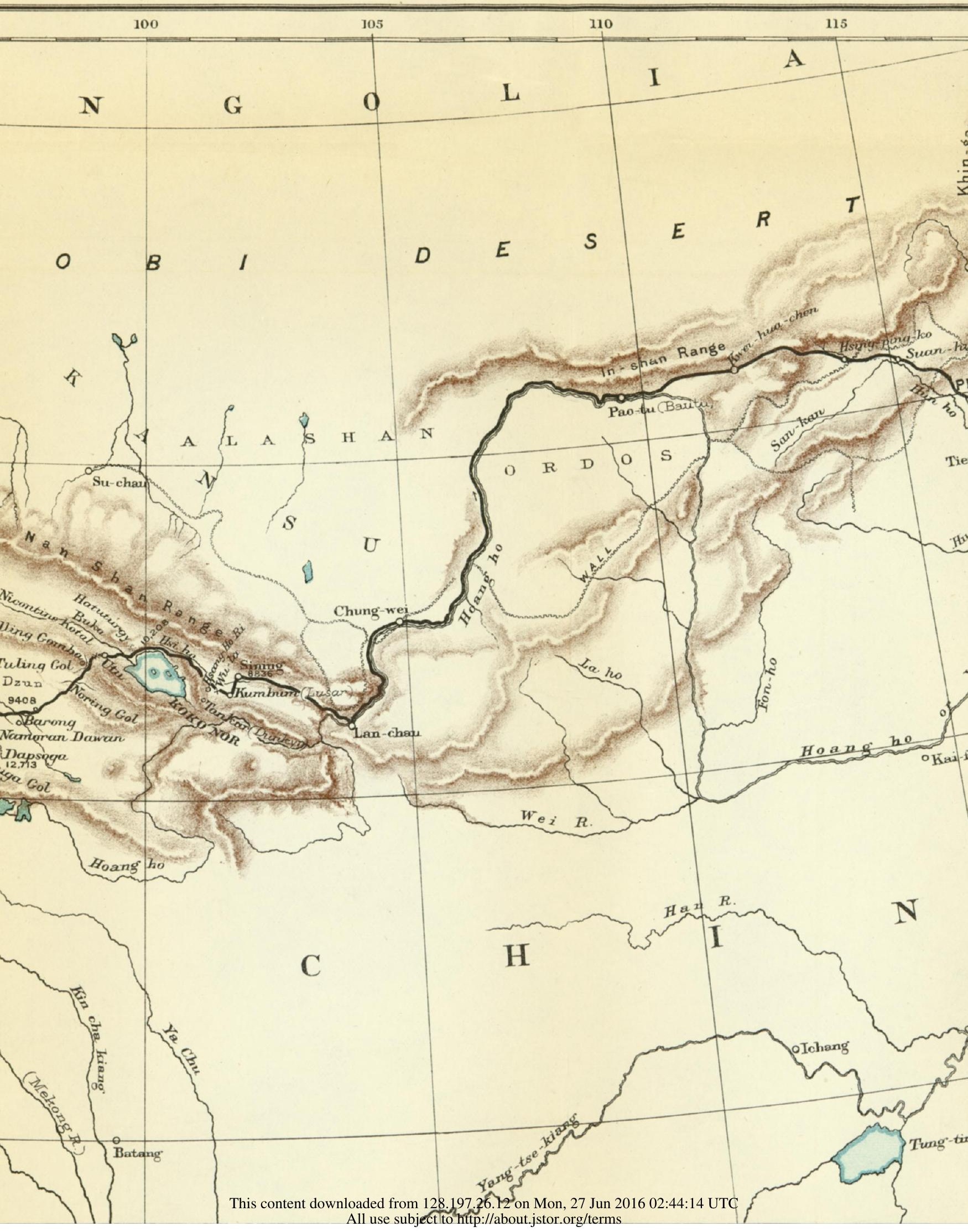




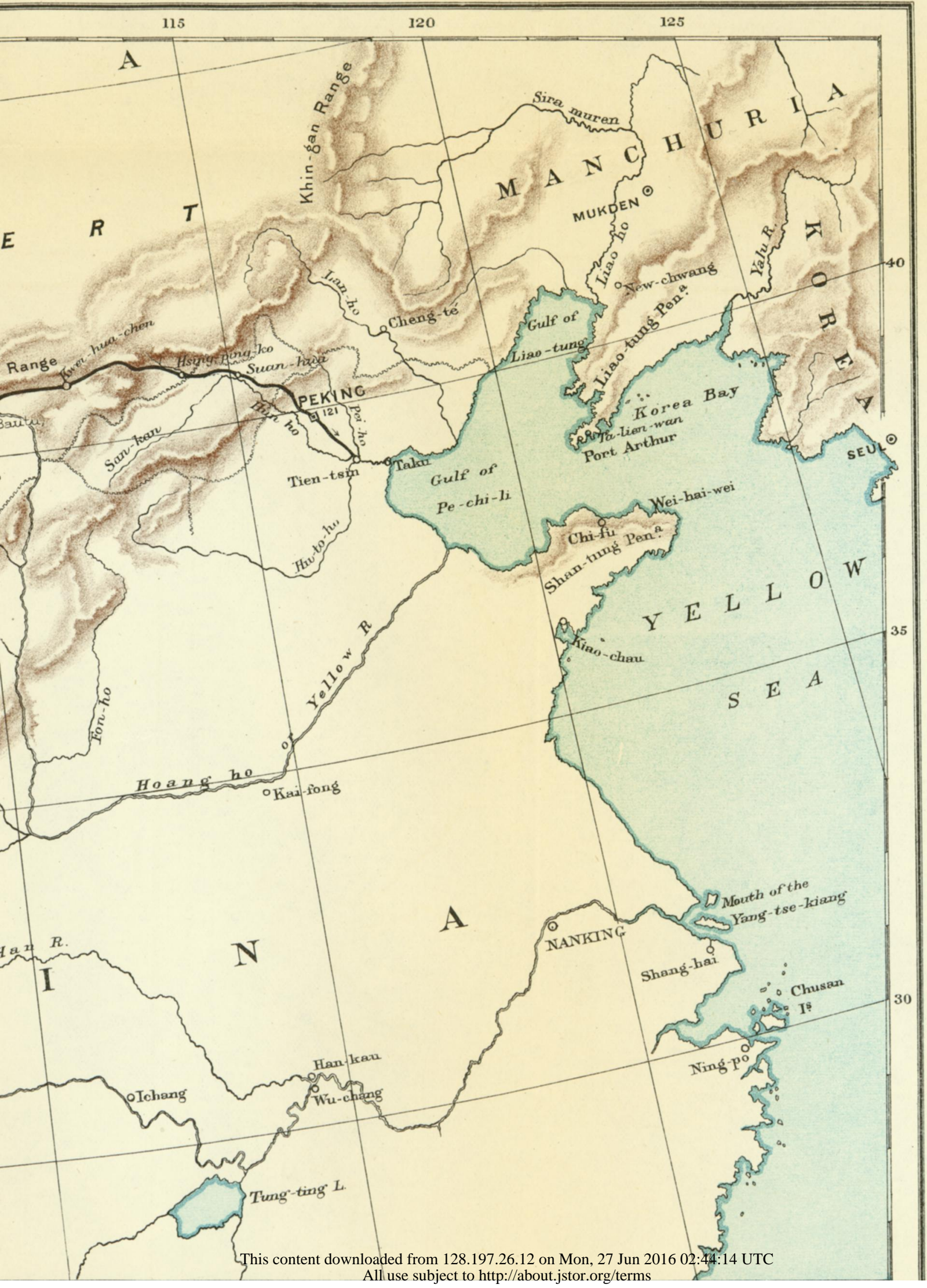




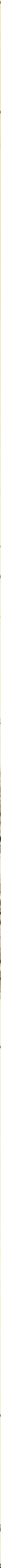

Published by the Royal Greographical Society 



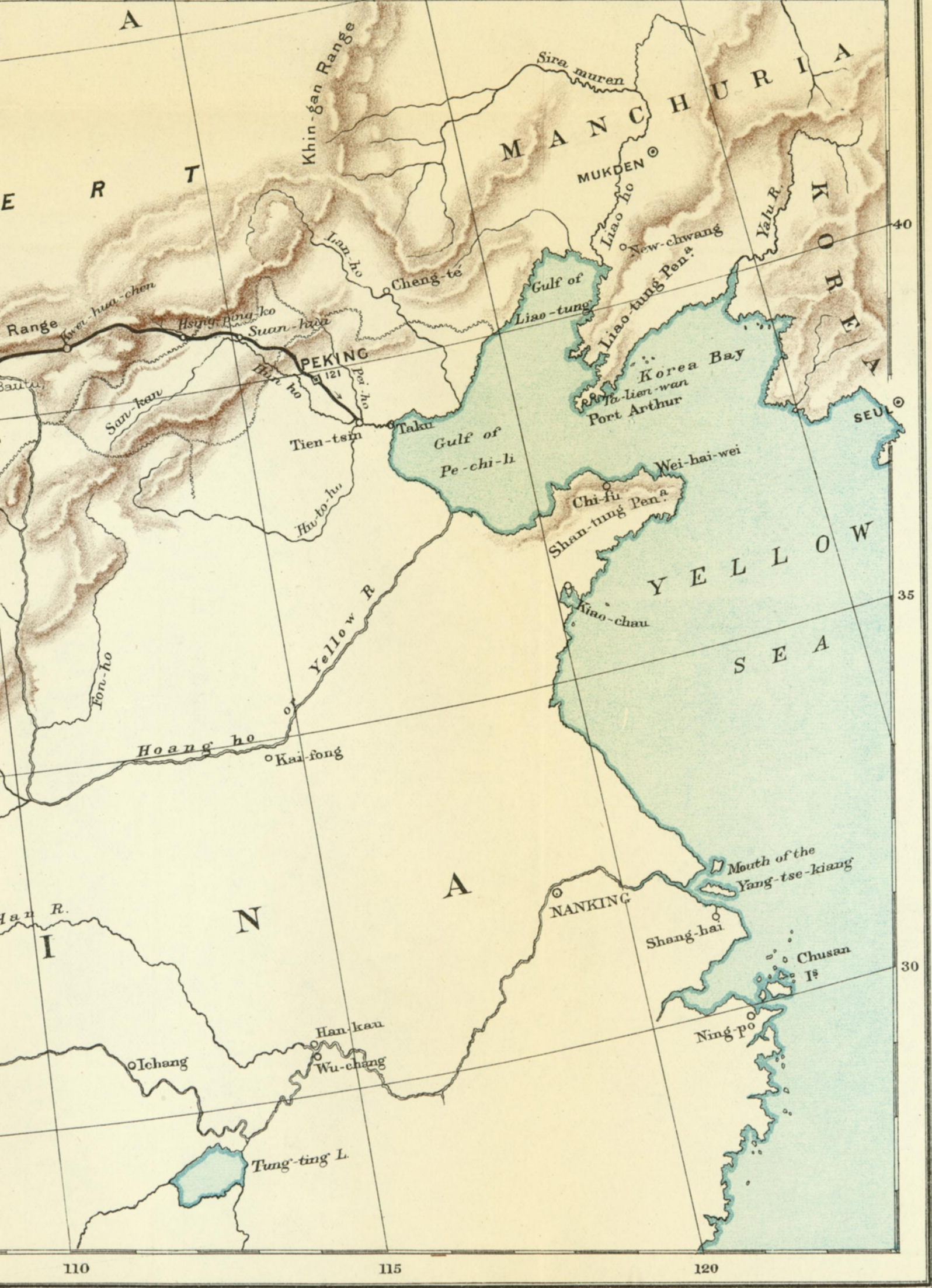

